\title{
The Effectiveness of Law Relating to Educational Right of Children with Disabilities in Malaysia
}

\author{
Muhammad Fikri Othman¹, Nur Ezan Rahmat² \\ ${ }^{1}$ Faculty of Law, Universiti Teknologi Mara (UiTM) Cawangan Sarawak, Malaysia \\ ${ }^{2}$ Faculty of Law, Universiti Teknologi Mara (UiTM) Shah Alam, Malaysia \\ muhammad300@uitm.edu.my, nurezan@uitm.edu.my \\ Tel: 019-3317559
}

\begin{abstract}
There are about 4.86 million persons with disabilities (PwDs) in Malaysia but only 1.58 per cent of them registered with the Malaysian Department of Social Welfare. The factor that must be taken into consideration to improve the quality of life of PwDs in Malaysia is their educational right since education is very important to someone's life, including children with disabilities. This paper discusses the effectiveness of the law relating to the educational right of children with disabilities in Malaysia through current laws and policies. Suggestions are also provided to improve the effectiveness of laws relating to their educational right.
\end{abstract}

Keywords: Children with disabilities; educational right; the effectiveness of the law

eISSN: 2398-4287@ 2020. The Authors. Published for AMER ABRA CE-Bs by e-International Publishing House, Ltd., UK. This is an open access article under the CC BYNC-ND license (http://creativecommons. org/licenses/by-nc-nd/4.0). Peer-review under responsibility of AMER (Association of Malaysian Environment-Behaviour Researchers), ABRA (Association of Behavioural Researchers on Asians) and cE-Bs (Centre for Environment-Behaviour Studies), Faculty of Architecture, Planning \& Surveying, Universiti Teknologi MARA, Malaysia. DOI: https://doi.org/10.21834/ebpj.v5i15.2484

\subsection{Introduction}

There are about 4.86 million persons with disabilities (PwDs) in Malaysia but only 513,519 persons or 1.58 per cent registered with the Malaysian Department of Social Welfare (Nik Min, 2019). Based on this figure, there are about 440,000 children with disabilities, but only 120,243 of them are registered (UNICEF, 2019). According to Mohd Nor, Mohamad Aun and Aizan (2017), this low registration rate is due to the registration of disabled persons in Malaysia is done voluntarily. Therefore the actual number of persons with disability in Malaysia is uncertain.

Persons with Disabilities Act 2008 defines PwDs as "those who have long-term physical, mental, intellectual or sensory impairments, which in interaction with various barriers may hinder their full and effective participation in society" whereas children with disabilities according to Maciver et al. (2019) as "children with developmental problems such as visual impairment, hearing impairment, autism spectrum conditions, behavioural disorders and learning difficulties". The Malaysian government in improving the life of PwDs, including children with disabilities provides equal educational right toward them as provided under Section 28 of the Persons with Disabilities Act 2008. The section reads as follow "PwDs shall not be excluded from general education system based on disabilities and children with disabilities shall not be excluded from pre-school, primary, secondary and higher education, on an equal basis with persons or children without disabilities".

The Malaysian government introduced 'Zero Reject Policy' in 2019 to provide equal educational right toward children with disabilities where all children in Malaysia including children with disabilities and undocumented children will have access to education (Abdul

eISSN: 2398-4287@ 2020. The Authors. Published for AMER ABRA cE-Bs by e-International Publishing House, Ltd., UK. This is an open access article under the CC BYNC-ND license (http://creativecommons.org/licenses/by-nc-nd/4.0/). Peer-review under responsibility of AMER (Association of Malaysian Environment-Behaviour Researchers), ABRA (Association of Behavioural Researchers on Asians) and cE-Bs (Centre for Environment-Behaviour Studies), Faculty of Architecture, Planning \& Surveying, Universiti Teknologi MARA, Malaysia.

DOI: https://doi.org/10.21834/ebpj.v5i15.2484 
Rashid, 2018). In supporting this policy, RM23 million has been allocated by the Malaysian government in its 2020 budget to provide disabled-friendly facilities in national schools (Zulkifli, 2019).

Even though children with disabilities have been promised to enjoy the equal educational right, but there are a lot of barriers that have been faced by them to enjoy that right. According to a report by UNICEF, although the 'Zero Policy Reject' has been implemented, most of the children with disabilities face difficulties in term of having access to education. The existence of a tiered system for students with special needs and a lack of policy's execution plan lead to this problem (UNICEF, 2019).

This paper aims to review the effectiveness of law relating to the educational right of children with disabilities in Malaysia through current laws and policies namely Federal Constitution, Persons with Disabilities Act 2008, Education Act 1996 and its regulations and Malaysian Plan of Action for Persons with Disabilities. Suggestions are provided to improve the effectiveness of those laws to allow children with disabilities in Malaysia enjoy equal educational right as promised by the government.

\subsection{Educational Right for Children with Disabilities}

\subsection{Persons and Children with Disabilities and Education}

Persons with disabilities (PwDs) according to Article 1 of United Nations Convention on the Rights of Persons with Disabilities are "those who have long-term physical, mental, intellectual or sensory impairments which in interaction with various barriers may hinder their full and effective participation in society on an equal basis with others". Abdullah and Hanafi (2017) stated the same definition has been adopted by Malaysian law to define PwDs based on Section 2 of the Persons with Disabilities Act by omitting the phrase "on an equal basis with others". Section 2 of the Act defines PwDs as "those who have long-term physical, mental, intellectual or sensory impairments which in interaction with various barriers may hinder their full and effective participation in society". Malaysian Education Blueprint 20132015 provides children with disabilities or students with special education needs as "students with visual impairment, hearing impairment, speech difficulties, physical disabilities, multiple disabilities and learning disabilities such as autism, Down's Syndrome, attention deficit hyperactivity disorder and dyslexia".

Education plays an essential role in securing a job and intellectual development for all. By having an education, persons and children with disabilities can write, read, seeking a job, making decisions and gain interpersonal skills. Besides, the United Declaration of Human Rights recognised education as part of human rights (Nadhir, Nasir, Nur, \& Erman, 2016). Therefore, education is needed by everyone, including persons and children with disabilities. This can be supported by Article 26 of the United Declaration of Human Rights 1948 , which stated that "everyone has the right to education" and it includes persons and children with disabilities. Besides, Article 28 of the United Nations Convention on the Rights of the Child 1989 provides an equal educational right to every child and allow no discrimination on disabilities basis to access education. This right has been fully supported by The World Conference on Education for All 1990, The Salamanca Statement 1994 and Convention on the Rights of Persons with Disabilities 2006 (Minou, 2011).

\subsection{System of Education for Children with Disabilities in Malaysia}

Due to the importance of education to all persons including those with disabilities, the Malaysian government through Ministry of Education provides three options of education for children with disabilities as mentioned under the Malaysian Education Blueprint 20132025 to provide an equal educational right for all children. The three options are Special Education Programme, Special Education Integration Programme (SEIP) and the Inclusive Education Programme (IEP). As of June 2019, there are 87,574 students enrolled in these programmes (2492 students under the Special Education Programme, 68874 students under SEIP and 16208 under IEP) (Kannan, 2019). These three programmes are different from each other and have their objectives and purposes.

Special Education Programme is a programme to provide education to children with disabilities and other marginalized children (Nadhir, Nasir, Nur, \& Erman, 2016). Based on Buku Data Pendidikan Khas Tahun 2019, Currently, there are 34 Special Education schools across the country. Under this programme, there are few categories of Special Education, namely Visual Impaired, Hearing Impaired and Learning Disabilities. Special Education Students with Visual Impairment consists of students with visual problems in which they are having a limited vision and cannot see anything directly. According to Omar and Sulaiman (2018), the method of teaching and learning for students with visual impairment is customized to improve their academic achievement, such as the use of braille system.

Special Education Students with Hearing Impairment consists of students with the hearing problem such as deaf and hearing impaired. The difference between these two types of students is deaf students are 'unable to process linguistic information with or without hearing aid' whereas hearing impaired students or half-deaf students 'still have sufficient hearing loss to process linguistic information with or without hearing aid' (Omar and Sulaiman, 2018). The method of teaching and learning for students with hearing impairment is by using communication modes according to the needs and capabilities of the students such as Malay Language Code, facial expression, lip reading, body language and hand code.

Special Education with Learning Disabilities consists of students with learning disabilities such as Autism, Down Syndrome, Slow Learner, Attention Deficit Hyperactivity Disorder, Dyslexia and Mental retarded. These students have neurological problems that cause learning process is hard for them since their speech, thinking, understanding and writing are affected by this neurological problem (Omar and Sulaiman, 2018). The method of teaching and learning for students with learning disabilities is based on Special Education Curriculum and Alternative Curriculum. According to Human Rights Commission of Malaysia (2015), Special Education Curriculum includes special curriculum and skill training curriculum as modified by Registrar General of Educational Institutions and Teachers 
whereas Alternative Curriculum includes basic reading and writing, calculation skills, manipulative skills, physical exercises, arts and music.

Special Education Integration Programme (SEIP) on the other hand, is a programme whereby special classes for students with special needs are provided in mainstream schools. (Mottan, 2015) In other word, students with special needs study in special classes in a mainstream school compared to the Special Education Programme where students with special needs study at special education schools. Under SIEP, students with special needs can learn in a normal learning environment since they can participate in schools' activities together with their normal friends and therefore improve their social skills. As mentioned before, SIEP is the most programme that has been enrolled by students with special needs in Malaysia with 68874 students as of June 2019 (Kannan, 2019).

Inclusive Education Programme (IEP) is a programme whereby students with special needs attend classes together with normal students. General education curriculum or mainstream curriculum is used by students with special needs. IEP is where students with special needs are placed in mainstream class and study with their normal peers (Omar and Sulaiman, 2018). Teng (2016) describes the idea of this programme is 'about enabling schools to serve all children' and 'transforming the educational system to accommodate the needs of students with special needs'.

In Malaysia, IEP is introduced to provide maximum interaction between students with special needs and normal students. Garis panduan Program Pendidikan Inklusif Murid Berkeperluan Khas (Edisi Percubaan) is used by the Ministry of Education to govern IEP. There are a few criteria under this guideline, including students' placement, students' criteria, teacher, assessment, and teaching and learning. Besides, Checklist for Inclusion Readiness is used by the ministry for student's enrolment into IEP. Students with special needs must fulfil certain criteria based on the Checklist for Inclusion Readiness before they can be admitted into schools.

\subsection{Current Laws and Policies Relating to Educational Right of Children with Disabilities in Malaysia}

\subsection{Federal Constitution}

The Federal Constitution is the highest law in Malaysia and comes into force in 1957. It is considered as the highest law of the land due to the concept of supremacy of the Federal Constitution as provided under Article 4. Article 4 of the Federal Constitution states "this Constitution is the supreme law of the Federation and any law passed after Merdeka Day which is inconsistent with this Constitution shall, to the extent of the inconsistency, be void". This means that any law which does not conform to any articles of the Federal Constitution will be considered as invalid.

On the part of the educational right for children with disabilities, Article 8 and Article 12 come into the picture. Article $8(1)$ states "all persons are equal before the law and entitled to the equal protection of the law". Furthermore, Article 12 states "without prejudice to the generality of Article 8, there shall be no discrimination against any citizen on the grounds only of religion, race, descent, or place of birth in the administration of any educational institution maintained by a public authority, and in particular, the admission of pupils or students or the payment of fees".

Based on Article 8 and Article 12 of the Federal Constitution, children with disabilities enjoy equal educational right as normal children since no citizen shall be discriminated in term of admission into an educational institution run by public authority. Besides, all citizens are equal before the law as provided by Article 8 .

\subsection{Persons with Disabilities Act 2008}

Abdullah, et al. (2017) mention the Malaysian government had enacted the Persons with Disabilities Act 2008 to ratify the United Nations Convention on the Rights of Persons with Disabilities in 2010. This act comes into force in 2008 after it was passed in the parliament in 2007. Section 28 of the Persons with Disabilities Act 2008 states "persons with disabilities shall not be excluded from the general education system on the basis of disabilities, and children with disabilities shall not be excluded from pre-school, primary, secondary and higher education, on an equal basis with persons or children without disabilities, including vocational training and lifelong learning".

Hence, children with disabilities have the right to access equal educational right based on Section 28 of the Persons with Disabilities Act 2008 and they should not be left behind due to their disabilities. Also, this section upholds the right to education as provided by Article 12 of the Federal Constitution by stating children with disabilities can enjoy equal educational right same as other normal children.

\subsection{Education Act 1996 and its Regulations}

Education Act 1996 has come into force in 1996, which include provisions for Special Education. Under these provisions, students with special needs are divided into learning difficulties, hearing impairment and visual impairment (Ozel et al., 2017). Section 40 of the Act states "the Minister shall provide special education in special schools established under paragraph 34(1)(b) or in such primary or secondary schools as the Minster deems expedient". This section requires the Minister of Education to provide education for students with special needs and therefore prove that children with disabilities also have the right toward education. Besides, the Education (Special Education) Regulations and the Education (Special Education) Regulations 2013 further provide the requirements for children with disabilities to be admitted into special schools or designated primary and secondary schools.

\subsection{National Action Plan for Persons with Disabilities 2016-2022}

The Malaysian government formulates the National Action Plan for Persons with Disabilities 2016-2022 to protect the rights of PwDs. This plan is in line with the $11^{\text {th }}$ Malaysian Plan (RMK11), Malaysian Persons with Disabilities Policy and also Incheon Strategy. There 
are several goals under this plan, including improved access of PwDs to education and healthcare, social services and advocacy enhancement and upgrading Risk Disaster Management for PwDs. Besides, this plan is formulated to implement the provisions of the Persons with Disabilities Act 2008 that has been enacted by the Malaysian government to ratify the United Nations Convention on the Rights of Persons with Disabilities in 2010.

\subsection{Methodology}

The researchers adopt a doctrinal analysis in this paper. In 2018 Kharel defines doctrinal analysis as "enquiry in legal concepts, values, principles and existing legal text such as statutes, case laws etc.". The researchers analyze journal articles, textbooks and encyclopedias which are related to special education for children with disabilities in Malaysia to understand and summarize the special education for children with disabilities and related law.

\subsection{Findings}

Even though the Malaysian government provides a great system of education for children with disabilities and enacted several laws regarding their educational right, there are proves that the efforts taken are not convincing. On the part of the education system for children with disabilities, the implementation of teaching and learning in special schools are limited due to lack of resources, teaching materials and facilities (Nadhir, Nasir, Nur, \& Erman, 2016). Besides, Rajaendram in 2014 stated students with special needs in SIEP learn in the same class although they possess different competency level. Therefore, the process of learning will be difficult for them and the teachers. For IEP, the guideline used is limited in term of its coverage. The normal students and students with special needs are given the same assessment and therefore lead to unsatisfactory results (Teng \& Jaffri, 2014). Additionally, a tiered system of education for children with disabilities that is practised in Malaysia caused IEP cannot be implemented effectively.

Baqutayan, Shamsul Khalil, Baharum and Abu Hassan (2016) argue that the current laws that have been enacted are insufficient. Article 8 of the Federal Constitution, which provides for equality among the citizen is lacking constitutional provision on discrimination towards PwDs. Article 12, which provides the right to education, does not prohibit against discrimination regarding the enrolment of students with special needs into designated schools. This is because the Ministry of Education sets certain criteria for them to be enrolled in those schools. Thus, the right of children with disabilities towards education is not effectively protected by the Federal Constitution.

Besides, the Persons with Disabilities Act 2008 has been criticized by many and regarded as 'toothless tiger' due to lack of enforcement provisions, discrimination against disabled persons and punishment for those who violate with this Act. This Act is also lacking provisions that prevent PwDs from being discriminated ${ }^{1}$. Moreover, the term "on equal basis" under Section 28 of this Act seems missing due to the existence of guideline by Ministry of Education for the enrollment of children with disabilities into the designated schools for them. Therefore, this Act is not effective to protect the educational right of children with disabilities in Malaysia.

Children with disabilities who can "manage themselves without help" and "educable" according to the Education (Special Education) Regulations 1997 are allowed to enrol into such programme. Hence, it shows that their educational right has been violated by this requirement. Even though this requirement has been abolished in 2013 under the Education (Special Education) Regulations 2013 and been replaced by a probationary period of 3 months, but it seems to carry the same effect as the previous requirement where children with disabilities must be "educable" to enrol into special education programmes. Plus, Baqutayan, et al. (2016) suggest that the National Plan of Action for Persons with Disabilities 2016-2022 that has been formulated by the Malaysian government is hard to be implemented due to the commitment shown by the parties involved are not impressive. This is because no clear departments are responsible for the outcomes of this plan, and in term of its implementation, there are no timelines given. Hence, the Regulations under the Education Act 1996 and the National Plan of Action for Persons with Disabilities 2016-2022 is not effective in protecting the educational right of children with disabilities in Malaysia.

\subsection{Conclusion \& Recommendations}

The Malaysian government had shown its commitment to protect the rights of persons with disabilities and provide the educational right for children with disabilities. However, it can be concluded that the commitment taken is not enough since the current laws that have been enacted are not effective due to the reasons mentioned above. The education system for children with disabilities also is not effective due to a tiered system that is practised in Malaysia. By amending the current laws and improving the education system for children with disabilities, the educational right for them can be protected effectively. More funds should be allocated to provide better facilities and teaching materials so that children with disabilities can enjoy a better learning experience. Besides, to effectively protect the rights of children with disabilities in Malaysia especially their educational right, it is time for the Malaysian government to formulate a legal framework of special education for children with disabilities in Malaysia and thus the children with disabilities, their parents and society will be benefited by the formulation of this legal framework.

\footnotetext{
${ }^{1}$ Amend 'toothless' act for the person with disabilities, urges group. Retrieved January 3, 2020 from

https://www.freemalaysiatoday.com/category/nation/2019/10/02/amend-toothless-act-for-persons-with-disabilities-urges-group/ 


\section{Acknowledgements}

Special thanks to the Ministry of Higher Education and Universiti Teknologi Mara (UiTM) for the financial supports through the Fundamental Research Grant Scheme (FRGS RACER) 2019.

\section{Paper Contribution to Related Field of Study}

This paper will contribute to the better understanding of laws relating to educational rights of children with disabilities in Malaysia among the citizen and will be beneficial to the children with disabilities, parents and the society.

\section{References}

Abdullah, N., Hanafi, H., \& Mohd Hamdi, N. I (2017). The Rights of Persons with Disabilities in Malaysia: The Underlying Reasons for Ineffectiveness of Persons with Disabilities Act 2008. International Journal for Studies on Children, Women, Elderly and Disabled, 1, 127- 134.

Nadhir, M., Nasir, A., Nur, A., \& Erman, A. (2016). Special education for children with disabilities in Malaysia: progress and obstacles. Geografia: Malaysian Journal of Society \& Space, 12(10), 78-87.

Abdul Rashid, H.R. (2018). Zero Reject Policy to be Implemented Next Year: Maszlee. Retrieved December 18, 2019 from ttps://www.nst.com.my/news/nation/2018/10/426683/zero-reject-policy-be-implemented-next-year-maszlee

Amend 'toothless' act for the person with disabilities, urges group. Retrieved January 3, 2020 from

https://www.freemalaysiatoday.com/category/nation/2019/10/02/amend-toothless-act-for-persons-with-disabilities-urges-group/

Baqatuyan, S. M., Shamsul Khalil, S. A., Baharum, N. A., \& Abu Hassan, N. (2016). Special Education for Children with Disabilities: A Review of the Current Policy and Practice in Malaysia. Journal of Advanced Review on Scientific Research, 25 (1), 1-10.

Human Rights Commission of Malaysia. (2015). The Right to Education for Children with Learning Disabilities: Focusing on Primary Education. Kuala Lumpur: Human Rights Commission of Malaysia.

Issue Brief: Children with Disabilities in Malaysia. (2019). Retrieved October 6, 2020 from https://www.unicef.org/malaysia/reports/issue-brief-children-disabilitiesmalaysia

Kannan, H. K. (2019) Education Ministry Registers 87,574 Special Needs Students as of June. Retrieved October 6, 2020 from https://www.nst.com.my/news/nation/2019/09/524752/education-ministry-registers-87574-special-needs-studentsjune\#: : :text=Education $\% 20$ Ministry\%20registers $\% 2087 \% 2$ C574\%20special\%20needs $\% 20$ students $\% 20$ as $\% 20$ of $\% 20$ June,By\%20Hashini\%20Kavishtri\&text=PUTRAJAYA\%3A\%20The\%20Education\%20Ministry\%20has,Datuk\%20Dr\%20Amin\%20Senin\%20today.

Kharel, A. (2018). Doctrinal Legal Research. SSRN Electronic Journal, 1-16.

Maciver, D., Rutherford, M., Arakelyan, S., Kramer, J. M., Richmond, J., Todorova,. L., et al. (2019). Participation of Children with Disabilities in School: A Realist Systematic Review of Psychosocial and Environmental Factors. PLoS One, 14(1).

Ministry of Education (MOE). (2013a). Garis Panduan Program Pendidikan Inklusif Murid Berkeperluan Khas (Edisi Percubaan). Bahagian Pendidikan Khas, Putrajaya: Malaysian Ministry of Education.

Minou, T. (2011) New Trends in Education of Children with Disabilities. Procedia Social and Behavioral Sciences, 15, 1955-1959.

Mohd Nor, M. I. H., Mohamad Aud, N. S., \& Amin, A. S. (2017). Challenges in Case Management of Persons with Mental Disabilities in Malaysia. Journal of Social Sciences and Humanities, Special Issue 3, 1-12.

Mottan, K. (2015). A Pilot Study into an Integrated Special Needs Programme using the CIPP Model (M2015). International Journal of Assessment and Evaluation in Education, 5, 57-66

Nik Min, N. A. M. (2019). Jumlah OKU Berdaftar JKM Masih Rendah. Retrieved November 17, 2019 from https://www.sinarharian.com.my/article/23353/BERITA/Nasional/Jumlah-OKU-berdaftar-JKM-masih-rendah

Omar, S. R, \& Sulaiman, A. Z. (2018). Implementation of Inclusive Education Programme for Special Education Need Students with Learning Disabilities in Malaysia. International Journal of Civilizational Studies and Human Sciences, 1(4), 85-95.

Ozel, E., Zhagan, M., Md Nor, M., Megat Daud, M. A. K., \& Nik Ali, N. A. (2017). The Human Right to Inclusive Education Under International Law: Malaysian's Concept. Journal of Global Business and Social Entrepreneurship (GBSE), 1(3), 234-243.

Rajaendram, R. (2014). Special needs learners face obstacles. Retrieved January 3, 2020 from https://www.thestar.com.my/news/education/2014/08/24/specialneeds-learners-face-obstacles

Teng, K. Y., Yeo, K. J., \& Jaffri, H. (2014). Implementation of Inclusive Education Programme in Malaysia. 1st International Education Postgraduate Seminar (IEPS), $1-8$.

Teng, K. Y. (2016). Contributions of Inclusive Education Programme, Teachers' Attitudes and Efficacy on Social Skills Among Students with Autism Spectrum Disorder. Unpublished doctoral dissertation, Universiti Teknologi Malaysia, Malaysia. 
Othman, M.F., et.al., AIVCE-BS-2, 2020ShahAlam, cE-Bs, FSPU, Universiti Teknologi MARA, Shah Alam, Malaysia, 02-03 Dec 2020, E-BPJ, 5(15), Dec 2020 (pp.275-280)

Zulkifli, Z. (2019). Education Ministry Largest 2020 Budget Recipient with RM64.1b. Retrieved December 18, 2019 from https://www.nst.com.my/news/governmentpublic-policy/2019/10/528981/education-ministry-largest-2020-budget-recipient-rm641b 